\title{
Comparative Mitogenomics of Two Critically Endangered Turtles, Batagur Kachuga and Batagur Dhongoka (Testudines: Geoemydidae): Implications in Phylogenetics of Freshwater Turtles
}

\author{
Ajit Kumar \\ Wildlife Institute of India \\ Prabhaker Yadav \\ Wildlife Institute of India \\ Aftab Usmani \\ Wildlife Institute of India \\ Syed Ainul Hussain \\ Wildlife Institute of India \\ Sandeep Kumar Gupta ( $\nabla$ skg@wii.gov.in ) \\ Wildlife Institute of India
}

\section{Research Article}

Keywords: Mitochondrial genome, freshwater turtles, phylogenetic analysis, genetic relationship, evolutionary patterns

Posted Date: July 13th, 2021

DOI: https://doi.org/10.21203/rs.3.rs-690457/v1

License: (c) (i) This work is licensed under a Creative Commons Attribution 4.0 International License. Read Full License 


\section{Abstract}

The Red-crowned roofed turtle (Batagur kachuga) and Three-striped roofed turtle ( $B$. dhongoka) are 'critically endangered' turtles in the Geoemydidae family. Herein, we generated the novel mitochondrial genome sequence of $B$. kachuga $(16,155)$ and $B$. dhongoka $(15,620)$ and compared it with other turtles species. Batagur mitogenome has 22 transfer RNAs (tRNAs), 13 protein-coding genes (PCGs), two ribosomal RNAs (rRNAs), and one control region (CR). The genome composition was biased toward A $+T$, with positive AT-skew and negative GC-skew. In the examined species, all 13 PCGs were started by ATG codons, except CO/gene, which was initiated by GTG. The majority of mito-genes were encoded on the heavy strand, except eight tRNAs and the ND6 region. We observed a typical cloverleaf structure for all tRNA, excluding tRNA $^{\text {Ser }}(A G N)$, where the base pairs of the dihydrouridine (DHU) arm were abridged. Bayesian Inference (BI) based phylogenetic analysis was constructed among 39 species from six Testudines families, exhibited a close genetic relationship between Batagur and Pangshura with a high supporting value (PP 0.99). It provides additional mitogenomic resources for further study of the Testudines evolutionary patterns.

\section{Introduction}

The genus Batagur in family Geoemydidae comprises six highly threatened testudine species (Fritz \& Havaš, 2007; Praschag et al., 2019). The Red-crowned roofed turtle (B. kachuga) and Three-striped roofed turtle (B. dhongoka) are two of the most critically endangered turtles in the IUCN Red List, limited to northern India (Ganga river basin), Nepal, and Bangladesh (Das et al., 2019; Praschag et al., 2019). Historically, both the species have been widespread in the Ganga and Brahmaputra basins, but its current distribution in the Brahmaputra basin needs reassessment (Rashid and Khan 2000; Choudhury et al. 2000). The batagur population has experienced a decline of over $80 \%$ across its range in the past 50 years, due to unsustainable anthropogenic pressure degrading riverine habitats, amplified by large scale poaching for wildlife trade for consumption and pet market (IUCN TFTSG and ATTWG 2000). Consequently, $B$. kachuga is suspected to got extinct from its range in Bangladesh (Praschag et al., 2019). Since 2005, B. dhongoka has been extirpated from the Gomti River, with a major population currently limited to the Chambal River National Sanctuary, India (Das et al., 2019). Hence, both B. Kachuga and B. dhongoka are given protection under national and international devices, such as Schedule I of the Indian Wild Life (Protection) Act, 1972, and Appendix I/ of the Convention on International Trade in Endangered Species of Flora and Fauna (CITES), respectively.

Comprehensive genetic information is a vital resource to study and develop our understanding of species biology and evolution. The availability of mitochondrial genome sequence has improved our comprehension of species identification among closely related taxa, genetic diversity, phylogenetic and evolutionary relationships (Boore et al., 1998; Galtier et al. 2009). Complete mitogenomes have been widely employed in Testudines systematic research, conservation, and biodiversity assessment (Galtier et al. 2009; Kundu et al., 2019; 2020). Feng et al. (2017) sequenced the mitochondrial genome of B. trivittata from genus Batagur. In the present study, we sequenced, annotated, and analyzed the mitochondrial genome of B. kachuga and B. dhongoka and perform a comparative analysis with other Geoemydid species. Furthermore, we reconstructed the phylogeny of Batagur with 38 Testudines species using mitogenome sequences to supplement the available resource on Batagur and elucidate its evolutionary affinities.

\section{Materials And Methods}

\subsection{Specimen collection and DNA isolation}

A small piece of tissue from B. kachuga and B.dhongoka was clipped off from the toe. The individuals were subsequently released in their habitat in the Turtle Breeding and Rehabilitation Centre, Sarnath, Varanasi under the Biodiversity Conservation and Ganga Rejuvenation Project, Wildlife Institute of India (WII), Dehradun. Samples were stored in 70\% ethanol till wet lab analysis. We used DNeasy Blood Tissue Kit (QIAGEN, Germany) to extract genomic DNA (gDNA) in a final elution volume of $100 \mu$ l. The extracted gDNA was examined by $1 \%$ agarose gel electrophoresis and then subsequently used to amplify the overlapping fragment of the mitogenome. The Institutional Animal Ethics Committee (IAEC) of WII has approved the experiments and samples collection method from turtles. This study is reported in accordance with ARRIVE guidelines, and all methods were carried out following relevant guidelines and regulations.

\section{Primers, PCR and sequencing}

The complete mitogenome sequences were amplified with 16 overlapping primers sets (Table S2) (Zhang et al., 2008a). PCR amplification was performed in $20 \mu \mathrm{l}$ reaction volume containing $1 \times$ standard PCR buffer, $1.5 \mathrm{mM} \mathrm{MgCl}, 0.25 \mathrm{mM}$ of each dNTPs, 4 pmol of each primer, 5 units of Taq DNA Polymerase (Thermo Fisher Scientific) and $1 \mu$ template DNA. The amplification program was set as follows: initial denaturation at $95^{\circ} \mathrm{C}$ for $5 \mathrm{~min}, 35 \mathrm{cycles}$ at $95^{\circ} \mathrm{C}$ for $45 \mathrm{sec}$, annealing at $55^{\circ} \mathrm{C}$ for $45 \mathrm{sec}$, initial extension at $72^{\circ} \mathrm{C}$ for $75 \mathrm{sec}$. and a final extension at $72^{\circ} \mathrm{C}$ for $10 \mathrm{~min}$. PCR products were checked and visualized on $2 \%$ agarose gel under a UV transilluminator. The PCR amplicons were cleaned with Exonuclease-I and shrimp alkaline phosphatase (Thermo Fisher Scientific) at $37^{\circ} \mathrm{C}$ for 20 min, followed by inactivation of 
enzymes at $85^{\circ} \mathrm{C}$ for $15 \mathrm{~min}$. The chemically cleaned PCR fragments were sequenced in 3500XL ABI Genetic Analyzer from both forward and reverse direction using BigDye Ver 3.1 Kit (ABI).

\subsection{Sequence analysis and gene annotation}

The overlapping mitogenome fragments were aligned and analyzed using Sequencher® Ver 5.4.6 (Gene Codes Corporation). All the mitogenome fragments were annotated against blast tools available from the NCBI (http://blast.ncbi.nlm.nih.gov/Blast). Further, the annotation and gene position of the contig sequence was confirmed with Mitos WebServer (Bernt et al., 2013) and MitoFish (Iwasaki et al., 2013). The complete mitogenome map of the Batagur was generated using CGView Server (Grant and Stothard, 2008). Nucleotide compositions, genetic code and mean pairwise genetic distances were calculated using MEGA X (Kumar et al., 2018). For estimating the bias in nucleotide composition in the mitogenomes, PCGs, tRNAs, and rRNAs, skew analysis was carried out using the following method: GC skew $=(G-C) /(G+C)$, AT skew $=(A-T) /(A+T)$ (Perna and Kocher et al., 1995). The overlapping regions and intergenic spacers among genes of the complete mitogenome were manually estimated. The sequences of PCGs were translated into putative amino acid sequences based on the vertebrate mitochondrial genetic code with the ExPasy translate tool. The tRNA genes were identified using the tRNAscan-SE Search Server (Lowe and Eddy, 1997), with default search mode.

\subsection{Sequence alignment and phylogenetic analysis}

In addition to the sequenced mitogenomes of $B$. kachuga and $B$. dhongoka, mitogenome sequences of 38 Testudines belonging to families Geoemydidae, Trionychidae, Emydidae, Platysternidae, Testudinidae, and Cheloniidae were downloaded from NCBI database (Table S1). The multiple alignments of the concatenated 13 PCGs were executed using MUSCLE, implemented in MEGA X (Kumar et al., 2018), and used for phylogenetic analyses. We employed Bayesian Inference (BI) analyses to construct a phylogenetic tree among Testudines using BEAST Ver 1.7 (Drummond et al., 2012). The general time-reversible model (GTR) with a gamma distribution (+ G) was selected for the concatenated genes based on AIC criteria generated in jModelTest Ver 2.1.10 (Darriba et al., 2012). The Monte Carlo Markov Chain (MCMC) was run for 10 million steps with a random starting tree, birth-death default priors, and sampled one tree every 1000 steps. We discarded the first $25 \%$ steps as burn-in. FigTree Ver 1.4.0 was used to visualize the resulting phylogenetic tree (http://tree.bio.ed.ac.uk/softw are/figtree/).

\section{Results And Discussion}

\subsection{Mitogenome structure and organization}

In the present study, we determined the mitochondrial genome sequences of $B$. kachuga (16,155 bp), and B. dhongoka (15,620 bp). The newly sequenced mitogenomes have been deposited in the GenBank database under accession numbers MZ242095 (for $B$. kachuga), and MZ242096 (for $B$. dhongoka). Similar to most vertebrates, the Batagur mitogenome comprised 37 genes: 13 PCGs (COXI-III, ND1-6, ND4L, CYTB, ATP6, and ATP8), 22 putative tRNA genes, two rRNA (12S and 16S) genes, and a non-coding region (Fig. 1). Among these, 28 genes (2 rRNA, 14 tRNA, and 12 PCGs) were located on the Heavy strand (H-strand), while the remaining nine genes (ND6 and 8 tRNAs) were found on the Light strand (L-strand) (Table 1). The gene order and arrangement were similar to those of other reported Testudines species (Kundu et al., 2019; 2020).

Table 1. Annotation of the mitochondrial genomes of Batagur kachuga and Batagur dhongoka. 


\begin{tabular}{|c|c|c|c|c|c|c|c|c|}
\hline \multirow[t]{2}{*}{ Gene } & \multirow[t]{2}{*}{ Strand } & \multirow[t]{2}{*}{ Anticodon } & \multicolumn{3}{|c|}{ Batagur kachuga } & \multicolumn{3}{|c|}{ Batagur dhongoka } \\
\hline & & & Position & Intergenic & Start/Stop & Position & Intergenic & Start/Stop \\
\hline tRNA-Phe & $\mathrm{H}$ & GAA & $1-70$ & 0 & - & $1-70$ & 0 & - \\
\hline 12S rRNA & $\mathrm{H}$ & - & 71-1035 & 0 & - & 71-1035 & 0 & - \\
\hline tRNA-Val & $\mathrm{H}$ & TAC & $1036-1105$ & 0 & - & $1036-1104$ & 0 & - \\
\hline 16S rRNA & $\mathrm{H}$ & - & $1105-2699$ & -1 & - & $1104-2710$ & -1 & - \\
\hline tRNA-Leu & $\mathrm{H}$ & TAA & $2701-2776$ & +1 & - & $2712-2787$ & +1 & - \\
\hline ND1 & $\mathrm{H}$ & - & $2777-3744$ & 0 & ATG/ TA- & $2788-3755$ & 0 & ATG/ TA- \\
\hline tRNA-lle & $\mathrm{H}$ & GAT & $3745-3814$ & 0 & - & $3756-3826$ & 0 & - \\
\hline tRNA-GIn & L & TTG & $3814-3884$ & -1 & - & $3826-3896$ & -1 & - \\
\hline tRNA-Met & $\mathrm{H}$ & CAT & $3884-3952$ & -1 & - & $3896-3964$ & -1 & - \\
\hline ND2 & $\mathrm{H}$ & - & $3953-4991$ & 0 & ATG/ T- & $3965-5003$ & 0 & ATG/ T- \\
\hline tRNA-Trp & $\mathrm{H}$ & TCA & $4992-5064$ & 0 & - & $5004-5076$ & 0 & - \\
\hline tRNA-Ala & L & TGC & $5066-5134$ & +1 & - & $5078-5146$ & +1 & - \\
\hline tRNA-Asn & L & GTT & $5136-5208$ & +1 & - & $5148-5220$ & +1 & - \\
\hline tRNA-Cys & L & GCA & $5235-5300$ & +26 & - & $5244-5309$ & +23 & - \\
\hline tRNA-Tyr & $L$ & GTA & $5301-5371$ & 0 & - & $5310-5380$ & 0 & - \\
\hline $\mathrm{COI}$ & $\mathrm{H}$ & - & $5373-6923$ & +1 & GTG/ AGG & $5382-6932$ & +1 & GTG/ AGG \\
\hline tRNA-Ser & L & TGA & $6912-6982$ & -12 & - & $6921-6991$ & -12 & - \\
\hline tRNA-Asp & $\mathrm{H}$ & GTC & $6983-7052$ & +0 & - & $6992-7061$ & +0 & - \\
\hline COII & $\mathrm{H}$ & - & $7053-7739$ & 0 & ATG/ TAA & $7062-7748$ & 0 & ATG/ TAA \\
\hline tRNA-Lys & $\mathrm{H}$ & TTT & 7741-7813 & +1 & - & $7750-7822$ & +1 & - \\
\hline ATP8 & $\mathrm{H}$ & - & $7815-7982$ & +1 & ATG/ TAA & 7824-7991 & +1 & ATG/ TAA \\
\hline ATP6 & $\mathrm{H}$ & - & 7973-8656 & -10 & ATG/ TAA & $7982-8665$ & -10 & ATG/ TAA \\
\hline COIII & $\mathrm{H}$ & - & $8656-9439$ & -1 & ATG/ T- & $8665-9448$ & -1 & ATG/ T- \\
\hline tRNA-Gly & $\mathrm{H}$ & TCC & $9440-9507$ & 0 & - & $9449-9516$ & 0 & - \\
\hline ND3 & $\mathrm{H}$ & - & $9509-9858$ & +1 & ATG/ T- & $9518-9867$ & +1 & ATG/ T- \\
\hline tRNA-Arg & $\mathrm{H}$ & TCG & 9859-9928 & 0 & - & $9868-9937$ & 0 & - \\
\hline ND4L & $\mathrm{H}$ & - & $9929-10225$ & 0 & ATG/ TAA & $9938-10234$ & 0 & ATG/ TAA \\
\hline ND4 & $\mathrm{H}$ & - & 10219-11595 & -7 & ATG/ TAG & $10228-11604$ & -7 & ATG/ TAG \\
\hline tRNA-His & $\mathrm{H}$ & GTG & $11604-11673$ & +8 & - & $11617-11685$ & +12 & - \\
\hline tRNA-Ser & $\mathrm{H}$ & $\mathrm{GCT}$ & $11674-11740$ & 0 & - & $11686-11752$ & 0 & - \\
\hline tRNA-Leu & $\mathrm{H}$ & TAG & $11740-11812$ & -1 & - & $11752-11824$ & -1 & - \\
\hline ND5 & $\mathrm{H}$ & - & $11813-13621$ & 0 & ATG/ TAA & $11825-13633$ & 0 & ATG/ TAA \\
\hline ND6 & L & - & $13617-14141$ & -5 & ATG/ AGA & $13629-14153$ & -5 & ATG/ AGG \\
\hline tRNA-Glu & $L$ & TTC & $14142-14209$ & 0 & - & $14154-14221$ & 0 & - \\
\hline CYTB & $\mathrm{H}$ & - & $14215-15354$ & +5 & ATG/ TAG & $14227-15366$ & +5 & ATG/ TAA \\
\hline tRNA-Thr & $\mathrm{H}$ & TGT & $15359-15431$ & +4 & - & $15371-15443$ & +4 & - \\
\hline tRNA-Pro & L & TGG & $15432-15502$ & 0 & - & $15444-15514$ & 0 & - \\
\hline
\end{tabular}




\begin{tabular}{|lllllll} 
Partial CR & $\mathrm{H}$ & - & $15503-16155$ & 0 & - & $15515-15620$
\end{tabular}

The sequenced mitogenomes displayed significant variation in size (Table 2). Notably, the length of $B$. dhongoka was the smallest among the available mitogenomes of Testudines due to partial amplification of CR. In addition, the differences in mitogenome length may be attributed to the size variation of the non-coding region among Testudines (Zheng et al., 2013). 
Table 2

Nucleotide composition in regions of the mitogenomes for Geoemydidae species.

\begin{tabular}{|c|c|c|c|c|c|c|c|c|c|c|c|c|}
\hline Species & $\begin{array}{l}\text { Mitogenome } \\
\text { (bp) }\end{array}$ & $\underset{\%}{A+T}$ & $\begin{array}{l}\text { AT- } \\
\text { skew }\end{array}$ & $\begin{array}{l}\text { GC- } \\
\text { skew }\end{array}$ & $\begin{array}{l}\text { PCGs } \\
\text { (bp) }\end{array}$ & $\begin{array}{l}A+T \\
\%\end{array}$ & $\begin{array}{l}\text { AT- } \\
\text { skew }\end{array}$ & $\begin{array}{l}\text { GC- } \\
\text { skew }\end{array}$ & $\begin{array}{l}\text { rRNAs } \\
\text { (bp) }\end{array}$ & $\begin{array}{l}A+T \\
\%\end{array}$ & $\begin{array}{l}\text { AT- } \\
\text { skew }\end{array}$ & $\begin{array}{l}\text { GC- } \\
\text { skew }\end{array}$ \\
\hline B. kachuga & 16,153 & 58.27 & 0.162 & -0.371 & 11,377 & 57.82 & 0.092 & -0.389 & 2,561 & 58.26 & 0.290 & -0.175 \\
\hline B. dhongoka & 15,619 & 57.76 & 0.165 & -0.372 & 11,378 & 57.44 & 0.089 & -0.381 & 2,573 & 58.26 & 0.303 & -0.181 \\
\hline B. trivittata & 16,463 & 58.12 & 0.156 & -0.366 & 11,379 & 57.44 & 0.092 & -0.386 & 2,568 & 57.78 & 0.289 & -0.173 \\
\hline P. tentoria & 16,657 & 59.44 & 0.120 & -0.331 & 11,295 & 58.52 & 0.052 & -0.348 & 2,562 & 58.86 & 0.265 & -0.155 \\
\hline P. sylhetensis & 16,568 & 59.27 & 0.124 & -0.334 & 11,268 & 58.77 & 0.056 & -0.345 & 2,561 & 59.00 & 0.273 & -0.173 \\
\hline M. sinensis & 16,461 & 60.02 & 0.126 & -0.340 & 11,395 & 59.54 & 0.064 & -0.354 & 2,570 & 58.94 & 0.272 & -0.177 \\
\hline M. caspica & 16,741 & 61.21 & 0.112 & -0.334 & 11,382 & 60.11 & 0.054 & -0.348 & 2,568 & 59.54 & 0.272 & -0.170 \\
\hline M. mutica & 16,775 & 60.79 & 0.122 & -0.335 & 11,392 & 59.37 & 0.058 & -0.345 & 2,568 & 59.46 & 0.266 & -0.164 \\
\hline M. rivulata & 16,766 & 61.22 & 0.121 & -0.332 & 11,382 & 60.09 & 0.054 & -0.346 & 2,567 & 59.36 & 0.272 & -0.169 \\
\hline M. reevesii & 16,783 & 61.04 & 0.119 & -0.329 & 11,377 & 59.84 & 0.063 & -0.350 & 2,573 & 59.89 & 0.265 & -0.176 \\
\hline M. japonica & 16,443 & 60.48 & 0.125 & -0.341 & 11,385 & 60.06 & 0.061 & -0.356 & 2,570 & 59.72 & 0.270 & -0.171 \\
\hline M. leprosa & 17,067 & 61.90 & 0.111 & -0.347 & 11,382 & 60.66 & 0.052 & -0.344 & 2,567 & 60.03 & 0.268 & -0.165 \\
\hline M. annamensis & 16,844 & 60.56 & 0.113 & -0.338 & 11,391 & 59.39 & 0.055 & -0.351 & 2,715 & 59.33 & 0.266 & -0.181 \\
\hline $\begin{array}{l}\text { M. } \\
\text { megalocephala }\end{array}$ & 16,783 & 61.25 & 0.111 & -0.338 & 11,385 & 60.11 & 0.052 & -0.346 & 2,574 & 59.82 & 0.267 & -0.176 \\
\hline M. nigricans & 16,779 & 60.93 & 0.118 & -0.336 & 11,382 & 59.65 & 0.056 & -0.346 & 2,570 & 59.80 & 0.277 & -0.186 \\
\hline C. dentata & 16,484 & 61.50 & 0.114 & -0.320 & 11,376 & 60.98 & 0.043 & -0.328 & 2,565 & 60.50 & 0.274 & -0.160 \\
\hline C. atripons & 16,500 & 61.62 & 0.117 & -0.321 & 11,387 & 61.05 & 0.044 & -0.329 & 2,561 & 60.71 & 0.275 & -0.165 \\
\hline $\begin{array}{l}\text { C. } \\
\text { pulchristriata }\end{array}$ & 16,527 & 61.57 & 0.116 & -0.324 & 11,380 & 60.80 & 0.044 & -0.333 & 2,564 & 60.68 & 0.276 & -0.164 \\
\hline $\begin{array}{l}\text { C. } \\
\text { tcheponensis }\end{array}$ & 16,593 & 60.97 & 0.121 & -0.323 & 11,377 & 60.13 & 0.042 & -0.327 & 2,576 & 59.66 & 0.284 & -0.170 \\
\hline C. oldhamii & 16,656 & 61.18 & 0.122 & -0.324 & 11,370 & 60.13 & 0.042 & -0.329 & 2,569 & 59.90 & 0.283 & -0.163 \\
\hline C. fusca & 16,491 & 61.29 & 0.118 & -0.326 & 11,382 & 60.80 & 0.045 & -0.338 & 2,563 & 60.32 & 0.274 & -0.162 \\
\hline C.galbinifrons & 17,244 & 61.70 & 0.106 & -0.348 & 11,399 & 60.03 & 0.049 & -0.342 & 2,571 & 60.13 & 0.271 & -0.184 \\
\hline $\begin{array}{l}\text { C. } \\
\text { flavomarginata }\end{array}$ & 16,721 & 61.67 & 0.102 & -0.331 & 11,377 & 60.51 & 0.038 & -0.339 & 2,562 & 60.34 & 0.262 & -0.159 \\
\hline C. aurocapitata & 16,890 & 60.98 & 0.100 & -0.331 & 11,373 & 59.30 & 0.051 & -0.343 & 2,577 & 59.48 & 0.274 & -0.160 \\
\hline C. pani & 16,922 & 61.10 & 0.102 & -0.331 & 11,393 & 59.39 & 0.047 & -0.345 & 2,568 & 59.50 & 0.276 & -0.161 \\
\hline C. trifasciata & 16,675 & 60.68 & 0.115 & -0.332 & 11,382 & 59.60 & 0.049 & -0.341 & 2,568 & 59.34 & 0.282 & -0.174 \\
\hline C. picturata & 16,623 & 60.85 & 0.116 & -0.335 & 11,395 & 60.03 & 0.049 & -0.340 & 2,553 & 59.61 & 0.282 & -0.179 \\
\hline C. amboinensis & 16,708 & 60.57 & 0.116 & -0.337 & 11,397 & 59.49 & 0.057 & -0.354 & 2,572 & 59.05 & 0.275 & -0.171 \\
\hline C. bourreti & 16,661 & 60.77 & 0.117 & -0.334 & 11,394 & 59.86 & 0.050 & -0.340 & 2,571 & 59.43 & 0.282 & -0.181 \\
\hline H. annandalii & 16,604 & 61.85 & 0.136 & -0.356 & 11,380 & 60.96 & 0.071 & -0.378 & 2,563 & 61.60 & 0.276 & -0.162 \\
\hline H. grandis & 16,581 & 62.38 & 0.112 & -0.334 & 11,379 & 61.96 & 0.051 & -0.348 & 2,566 & 61.10 & 0.267 & -0.160 \\
\hline H. depressa & 16,773 & 62.52 & 0.119 & -0.330 & 11,382 & 61.50 & 0.048 & -0.336 & 2,565 & 61.55 & 0.257 & -0.156 \\
\hline S. bealei & 16,564 & 61.01 & 0.120 & -0.330 & 11,373 & 60.39 & 0.053 & -0.347 & 2,574 & 59.98 & 0.270 & -0.165 \\
\hline $\begin{array}{l}\text { S. } \\
\text { quadriocellata }\end{array}$ & 16,555 & 61.11 & 0.121 & -0.333 & 11,366 & 60.32 & 0.052 & -0.346 & 2,859 & 59.39 & 0.261 & -0.164 \\
\hline
\end{tabular}




\begin{tabular}{|c|c|c|c|c|c|c|c|c|c|c|c|c|}
\hline Species & $\begin{array}{l}\text { Mitogenome } \\
\text { (bp) }\end{array}$ & $\begin{array}{l}A+T \\
\%\end{array}$ & $\begin{array}{l}\text { AT- } \\
\text { skew }\end{array}$ & $\begin{array}{l}\text { GC- } \\
\text { skew }\end{array}$ & $\begin{array}{l}\text { PCGs } \\
\text { (bp) }\end{array}$ & $\begin{array}{l}A+T \\
\%\end{array}$ & $\begin{array}{l}\text { AT- } \\
\text { skew }\end{array}$ & $\begin{array}{l}\text { GC- } \\
\text { skew }\end{array}$ & $\begin{array}{l}\text { rRNAs } \\
\text { (bp) }\end{array}$ & $\begin{array}{l}A+T \\
\%\end{array}$ & $\begin{array}{l}\text { AT- } \\
\text { skew }\end{array}$ & $\begin{array}{l}\text { GC- } \\
\text { skew }\end{array}$ \\
\hline N. platynota & 16,981 & 62.49 & 0.100 & -0.347 & 11,398 & 61.60 & 0.043 & -0.348 & 2,573 & 61.01 & 0.263 & -0.164 \\
\hline
\end{tabular}

The base composition for the $A+T$ bias of the $B$. kachuga and $B$. dhongoka mitogenome is $58.27 \%$ and $57.76 \%$, respectively (Table 2 ). It was identical to the nucleotide composition biases reported in other Testudines, ranging from $58.12 \%$ (B. trivittata) to $62.52 \%$ (Heosemys depressa). A significant bias towards A/T was also observed in the mitogenomes and the PCGs and rRNA of Batagur and other and Testudines. In Batagur, AT skewness was positive, which indicated that nucleotide adenine was more prevalent than thymine, whereas negative GC skewness showed that the cytosine was more common than the guanine base in complete mitogenome. Similar results have also been reported in several turtles, such as Pangshura spps. (Kundu et al., 2019; 2020), Cyclemys dentata (Huang et al., 2015), Pyxidea mouhotii (Zhang et al., 2008b), Cuora trifasciata (Li et al., 2015), and B. trivittata (Feng et al., 2017).

The nine pairs of the overlapping region in the mitogenomes were observed among $t R N A^{V a l} / 16 \mathrm{SrRNA}, \mathrm{tRNA} / \mathrm{le} / \mathrm{tRNA} A^{\mathrm{Gln}}, \mathrm{tRNA} A^{\mathrm{Gln}} / \mathrm{tRNA}^{\mathrm{Met}}$, COI/tRNA ${ }^{\text {Ser }}$, ATP8/ATP6, ATP6/COIII, ND4L/ND4, tRNA ${ }^{\text {Ser/tRNA }}{ }^{\text {Leu }}$ and ND5/ND6. The overlapping regions were ranged from - 1 to -12 bp.

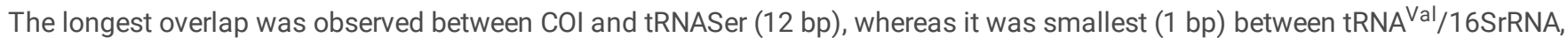

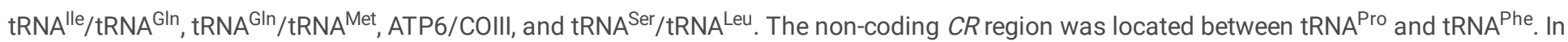
addition, the longest intergenic spacers (26 bp in $B$. kachuga and $23 \mathrm{bp}$ in $B$. dhongoka) were observed between the tRNA ${ }^{\text {Asn }}$ and tRNA ${ }^{\text {Cys }}$ mitochondrial regions (Table 1). The mitogenome-based genetic differentiation showed $7.6 \%$ variation between $B$. dhongoka and $B$. kachuga, $7.7 \%$ between $B$. kachuga and B. trivittata, whereas it was slightly low between B. dhongoka and B. trivittata at $6.3 \%$ (Fig. 2).

\subsection{Protein-coding genes}

In the mitogenomes of Batagur, the 13 PCGs were $11,377 \mathrm{bp}$ (B. kachuga), and 11,378 bp (B. dhongoka) in size and comprise an AT content of $57.82 \%$ and $57.44 \%$, respectively. The size of PCGs in studied Testudines ranged from 11,268 bp (P. sylhetensis) to 11,399 bp (Cuora galbinifrons) (Table 2). As with other Testudines, only one region (ND6) of the 13 PCGs of Batagur mitogenome occurred on the L-strand, while the remaining twelve including six NADH dehydrogenases subunits (ND1, ND2, ND3, ND4, ND5, and ND4L), three cytochrome $c$ oxidases (COI, COII, and COIII), two ATP synthase (ATP6 and ATP8) and one cytochrome $b$ (Cyt $b$ ) gene were located on the H-strand. The average AT and GC skews values for B. kachuga and B. dhongoka in PCGs were 0.092 and -0.389 , and 0.089 and -0.381 , respectively (Table 2). Of the 13 PCGs, twelve were initiated with codon ATG, while COl utilized GTG (valine) as start codon. The initiation codon ATG is commonly found in most Testudines (Kundu et al., 2019; 2020; Feng et al., 2017) and mammalian species (Kumar et al., 2019; Kumar et al., 2020), and GTG start codon in CO/is highly conserved across Geoemydid species (Kundu et al., 2019).

All the PCGs of the analyzed sequences terminate with a complete or incomplete stop codon. There are five genes (COII, ATP8, ATP6, ND4L and ND5) that end with TAA as the stop codon, ND4 end with TAG, CYTB end with TAG and TAA in B. kachuga and $B$. dhongoka, respectively, while COI ends with AGG. In $B$. kachuga, ND6 gene terminates with AGA, while $B$. dhongoka terminates with AGG. While four genes (ND1, ND2, COIII, and ND3) terminate with an incomplete stop codon (Table 1). The presence of incomplete stop codons is a common characteristic across vertebrate mitogenome, and these incomplete stop codons are likely a result of post-transcriptional modification during the mRNA maturation process (Ojala et al., 1981).

The relative synonymous codon usage (RSCU) values of the PCGs in B. kachuga and $B$. dhongoka are summarized in Fig. 3 . The total number of codons in PCGs is 3791 (B. kachuga), and 3790 (B. dhongoka). The RSCU analysis revealed that isoleucine, leucine and threonine are the most abundant amino acid, whereas methionine and cysteine were relatively less abundant. The same usage was observed in other Geoemydid species (Kundu et al., 2019).

We recovered high genetic differentiation between B. dhongoka and B. kachuga, in ATP8 (15.1\%) and ND6 genes (14.4\%), whereas it was low in COX// gene (2.1\%). All genes showed considerable differentiation among the three Batagur species (Fig. 2).

\subsection{Transfer RNA, ribosomal RNA and Control region}

The mitogenome of Batagur contained typical 22 tRNA genes, identical to those seen in other turtle species. The length of the tRNA was varied, ranging from 66 (tRNA ${ }^{\text {Cys }}$ ) to 76 bp (tRNA ${ }^{\text {Leu }}$ ). Among 22 tRNA genes, 14 were encoded on the $\mathrm{H}$-strand, while eight were located on the L-strand (Fig. 1 and Table 1). All tRNA genes folded into a classic secondary cloverleaf shape, except (tRNA ${ }^{\text {Ser }}$ ). Instead of a conserved stem-loop structure, tRNA ${ }^{\text {Ser }}$ 'DHU' arm showed a large loop structure (Fig S1). The two ribosomal RNA subunits genes (12S and 16S) were situated between tRNA ${ }^{\text {Phe }}$ - tRNA ${ }^{\mathrm{Val}}$, and tRNA ${ }^{\mathrm{Val}}$ - tRNA ${ }^{\text {Leu }}$, respectively (Fig. 1). The length of concatenated rRNA was 2,561 bp in $B$. kachuga, and 2,573 bp in B. dhongoka, with an A+T content of $58.26 \%$. The average AT and GC skews values in rRNA for $B$. kachuga were 
0.290 and -0.175 , and for $B$. dhongoka were 0.303 and -0.181 , respectively. Both $12 S$ rRNA and 16 S rRNA genes showed low genetic differentiation between $B$. dhongoka and $B$. trivittata (3.8\% and $3.4 \%$, respectively), whereas almost equal values were observed between $B$. dhongoka/B. kachuga and B. kachuga/B. trivittata for both the genes (Fig. 2). The location, nucleotide characteristics, and genetic differentiation in the rRNAs indicated that rRNAs are conserved and hold valuable phylogenetic information sites.

The CR of Batagurmitogenome resides between tRNA ${ }^{\text {Pro }}$ and tRNA ${ }^{\text {Phe }}$. In the present study, we partially sequenced the CR of $B$. kachuga (653 bp) and $B$. dhongoka (106 bp). Moreover, in the mitogenome of $B$. trivittata, the size of CR is 947 bp in length and is located with an A+ T content of $64.9 \%$ (Feng et al., 2017). In the other turtle species, the length of CR varied from 600 bp (Lepidochelys olivacea) to 1,722 bp (Cuora galbinifrons) with high AT content. The CR is also known as A + T rich region, which contains a signal for regulation and initiation of transcription and replication of the mitogenome (Clayton, 1992).

\subsection{Phylogenetic analyses}

A total of 40 species of Testudines were used for the phylogenetic analysis based on their 13 PCGs, including 3 species from subfamily Batagurinae, 32 from Geoemydinae, and five from other families in Testudines (Table S1). The generated mitogenome of $B$. kachuga and $B$. dhongoka yielded a robust BI based phylogeny and established its relationship with $B$. trivittata, $P$. tentoria and $P$. sylhetensis of Batagurinae subfamily with high posterior probability (PP 0.99) (Fig. 4). The resulting clustering pattern supports establishing a separate subfamily for Batagur and Pangshura, which is consistent with the viewpoint proposed by (Gaffney and Meylan, 1988; Kundu et al., 2019). Till date, the complete mitogenome of only three species of Batagurinae subfamily is available. Hence the denovo assembly of two critically endangered turtles generated genetic resources in the global database. Additionally, the family Geoemydidae was separated into two subfamilies Geoemydinae and Batagurinae, based on morphological data, and Kachuga trivittata, Kachuga smithii, Kachuga tentoria and Kachuga tecta grouped into subfamily Batagurinae (Hirayama, 1984). The obtained Testudines phylogeny and the relationship of Batagur are largely consistent with previous results (Kundu et al., 2019; 2020). Additionally, the genus Cuora is close to Mauremys, whereas Cyclemys, Sacalia, Heosemys, and Notochelys are clustered separately with significant posterior probability support.

\section{Conclusion}

The phylogenetic relationship of Asian turtle species is poorly understood due to the unavailability of taxon sequences. The evolutionary relationship of Batagur among the Geoemydidae has not been fully resolved due to the unavailability of complete mitogenomes of $B$. kachuga and $B$. dhongoka. Therefore, this study described the first mitogenomic characterization of the critically endangered $B$. kachuga and $B$. dhongoka and compared them with other turtle species. Consistent with previous observations of other related turtle species, the mitogenome of $B$. kachuga and $B$. dhongoka was highly conserved in gene content, gene size, gene order, base composition, and PCG codon usage, as well as tRNA and rRNA secondary structures. Both the studied species have small population sizes and isolated distribution ranges that could be a barrier to their genetic connectivity leading to loss of genetic diversity. Hence, the comprehensive understanding of genetic variations at the mitogenomic level is vital to guide science-based conservation efforts for its long-term survival and sustenance. The present study provides the baseline information for genetic monitoring, spatial distribution ranges, and evolutionary relationships. In this context, adding more species and genes to the turtle's mitogenomic repository will resolve evolutionary dynamics among the major Testudines lineages.

\section{Declarations}

\section{Acknowledgment}

We acknowledge the support provided by Dr. Dhananjai Mohan, Director, Dr. YV Jhala, Dean and Dr. Ruchi Badola, Nodal Officer, National Mission for Clean Ganga (NMCG), WII and the entire project team of NMCG. We thank the state Forest Department of Uttar Pradesh for their support.

\section{Funding}

This study was funded by the National Mission for Clean Ganga (NMCG) project of the Ministry of Jal Shakti through Grant Number B/02/2015-16/1259/NMCG.

\section{Conflicts of interest/Competing interests}

The author(s) declare no competing interests.

\section{Availability of data and material}


Sequence data are available through NCBI GenBank (MZ242095 and MZ242096)

Code availability Not applicable

\section{Authors' contributions}

SKG designed the methodological framework of the study. SAH acquired resources and funding for the project. AK, PY and AU collected biological samples. AK \& PY generated a sequence. AK, PY and SKG analyzed data and compiled this paper. All authors approved the final version of the article.

\section{Ethics approval}

Institutional Animal Ethics Committee (IAEC), Wildlife Institute of India, has approved the method of collection of biological samples for the present study.

Consent to participate Not application (No human research data are used)

Consent for publication Not applicable

\section{References}

1. Boore, J.L., Brown, W.M., 1998. Big trees from little genomes: mitochondrial gene order as a phylogenetic tool, Curr. Opin. Genet. Dev. 8, 668-674.

2. Choudhury B.C., Bhupathy, S., Hanfee, F., 2000. Status information on the tortoises and freshwater turtles of India. In: P.P. van Dijk, B.L. Stuart and A.G.J. Rhodin (eds), Asian Turtle Trade: Proceedings of a Workshop on Conservation and Trade of Freshwater Turtles and Tortoises in Asia. In: P.P. van Dijk, B.L. Stuart and A.G.J. Rhodin (eds), Asian Turtle Trade: Proceedings of a Workshop on Conservation and Trade of Freshwater Turtles and Tortoises in Asia. Chelonian Research Monographs No. 2, pp. 86-94. Chelonian Research Foundation, Lunenburg, MA, USA.

3. Clayton, D.A., 1992. Transcription and replication of animal mitochondrial DNA, Int.Rev. Cytol. 141, $217-232$.

4. Darriba, D., Taboada, G.L., Doallo, R., Posada, D., 2012. jModelTest 2: more models, new heuristics and parallel computing. Nat. Methods 9:772.

5. Das, I., Choudhury, B.C., Praschag, P., Ahmed, M.F., Singh, S., 2019. Batagur dhongoka (errata version published in 2019). The IUCN Red List of Threatened Species 2019: e.T10953A152042542.

6. Drummond, A.J., Suchard, M.A., Xie, D., Rambaut, A., 2012. Bayesian phylogenetics with BEAUti and the BEAST 1.7. Mol. Biol. Evol. 29,1969-1973.

7. Feng, L., Yang, J., Zhang, Y.P. and Zhao, G.F., 2017. The complete mitochondrial genome of the Burmese roofed turtle (Batagur trivittata) (Testudines: Geoemydidae). Conserv. Genet. Resour., 9, 95-97.

8. Fritz, U., Havas, P., 2007. Checklist of Chelonians of the World. Bonn and Dresden: German Federal Ministry of Environment, Nature Conservation and Nuclear Safety and Museum of Zoology Dresden.

9. Fund, T.C., 2002. A global action plan for conservation of tortoises and freshwater turtles. Strategy and funding prospectus $2007,30$.

10. Gaffney, E.S., Meylan, P.A., 1988. A phylogeny of turtles. In M. J. Benton (Ed.), The phylogeny and classification of tetrapods (pp. 157219). Oxford, UK: Clarendon Press.

11. Galtier, N., Nabholz, B., Glémin, S., Hurst, G.D.D., 2009. Mitochondrial DNA as a marker of molecular diversity: a reappraisal. Mol. Ecol 18, 4541-4550.

12. Grant, J. R., Stothard, P., 2008. The CGView Server: A comparative genomics tool for circular genomes. Nucleic Acids Res, 36, W181W184.

13. Hirayama, R., 1984. Cladistic analysis of batagurine turtles (Batagurinae: Emydidae: Testudinoidea): a preliminary result. $141-157$.

14. Huang, Y. N., Li, J., Jiang, Q. Y., Shen, X. S., Yan, X. Y., Tang, Y. B., Huang, J., Guo, Y.F., Lan, G.Q., Jiang, H. S., 2015. Complete mitochondrial genome of the Cyclemys dentate and phylogenetic analysis of the major family Geoemydidae. Genet. Mol. Res, 14, 32343243.

15. IUCN TFTSG and ATTWG (IUCN/SSC Tortoise and Freshwater Turtle Specialist Group and Asian Turtle Trade Working Group). 2000. Recommended changes to 1996 IUCN Red List Status of Asian turtle species. In: P.P. van Dijk, B.L. Stuart and A.G.J. Rhodin (eds), Asian Turtle Trade: Proceedings of a Workshop on Conservation and Trade of Freshwater Turtles and Tortoises in Asia. Chelonian Research Monographs, Number 2, pp. 156-164. Chelonian Research Foundation, Lunenburg, MA, USA.

Page 9/14 
16. Kumar, A., Gautam, K.B., Singh, B., Yadav, P., Gopi, G.V., Gupta, S.K., 2019. Sequencing and characterization of the complete mitochondrial genome of Mishmi takin (Budorcas taxicolor taxicolor) and comparison with the other Caprinae species. Int. J. Biol. Macromol. 137, 87-94.

17. Kumar, A., Yadav, P., Usmani, A., Hussian, S.A., Gupta, S.K., 2021. Complete mitogenome of Ganges river dolphin, Platanista gangetica gangetica and its phylogenetic relationship with other cetaceans. Mol. Biol. Rep, 48(1), pp.315-322.

18. Kumar, S., Stecher, G., Li, M., Knyaz, C., Tamura, K., 2018. MEGA X: molecular evolutionary genetics analysis across computing platforms. Mol. Biol. Evol. 35, 1547-1549.

19. Kundu, S., Kumar, V., Tyagi, K., Chakraborty, R., Chandra, K., 2019. The first complete mitochondrial genome of the Indian Tent Turtle, Pangshura tentoria (Testudines: Geoemydidae): Characterization and comparative analysis. Ecol. Evol, 9 (18): 1-15.

20. Kundu, S., Kumar, V., Tyagi, K., Chandra, K., 2020. The complete mitochondrial genome of the endangered Assam Roofed Turtle, Pangshura sylhetensis (Testudines: Geoemydidae): Genomic features and phylogeny. PLoS ONE 15(4): e0225233.

21. Li, W., Zhang, X.C., Zhao, J., Shi, Y., \& Zhu, X.P., 2015. Complete mitochondrial genome of Cuora trifasciata (Chinese three striped box turtle), and a comparative analysis with other box turtles. Gene, 555, 169-177

22. Lowe, T.M., Eddy, S.R., 1997. tRNAscan-SE: a program for improved detection of transfer RNA genes in genomic sequence, Nucleic Acids Res. 25, 955-964.

23. Ojala, D., Montoya, J., Attardi, G., 1981. tRNA punctuation model of RNA processing in human mitochondrial, Nature 290, 470-474.

24. Perna, N.T., Kocher, T.D., 1995. Patterns of nucleotide composition at fourfold degenerate sites of animal mitochondrial genomes. J. Mol. Evol., 41, 353-358.

25. Praschag, P., Ahmed, M.F., Das, I., Singh, S., 2019. Batagur kachuga (errata version published in 2019). The IUCN Red List of Threatened Species 2019: e.T10949A152043133.

26. Rashid, S.M.A., Khan, S.M.M.H., 2000. Trade and Conservation Status of Freshwater Turtles and Tortoises in Bangladesh. In: P.P. van Dijk, B.L. Stuart and A.G.J. Rhodin (eds), Asian Turtle Trade: Proceedings of a Workshop on Conservation and Trade of Freshwater Turtles and Tortoises in Asia. Chelonian Research Monographs No. 2, pp. 77-85. Chelonian Research Foundation, Lunenburg, MA, USA.

27. Zhang, L., Nie, L.W., Zhang, Y., Rui, J.L., Zhang, Y.Y., 2008a. Complete sequence and organization of the mitochondrial genome of Cyclemys atripons (Testudines, Geoemydidae). Genet. Mol. Biol., 31, 783-788.

28. Zhang, L., Nie, L., Cao, C., Zhan, Y. 2008b. The complete mitochondrial genome of the Keeled box turtle Pyxidea mouhotii and phylogenetic analysis of major turtle groups. J Genet. Genomics, 35, 33-40.

29. Zheng, C., Nie, L., Wang, J., Zhou, H., Hou, H., Wang, H., Liu, J., 2013. Recombination and evolution of duplicate control regions in the mitochondrial genome of the Asian Big-Headed turtle, Platysternon megacephalum. PLoS ONE 8, e82854.

\section{Figures}




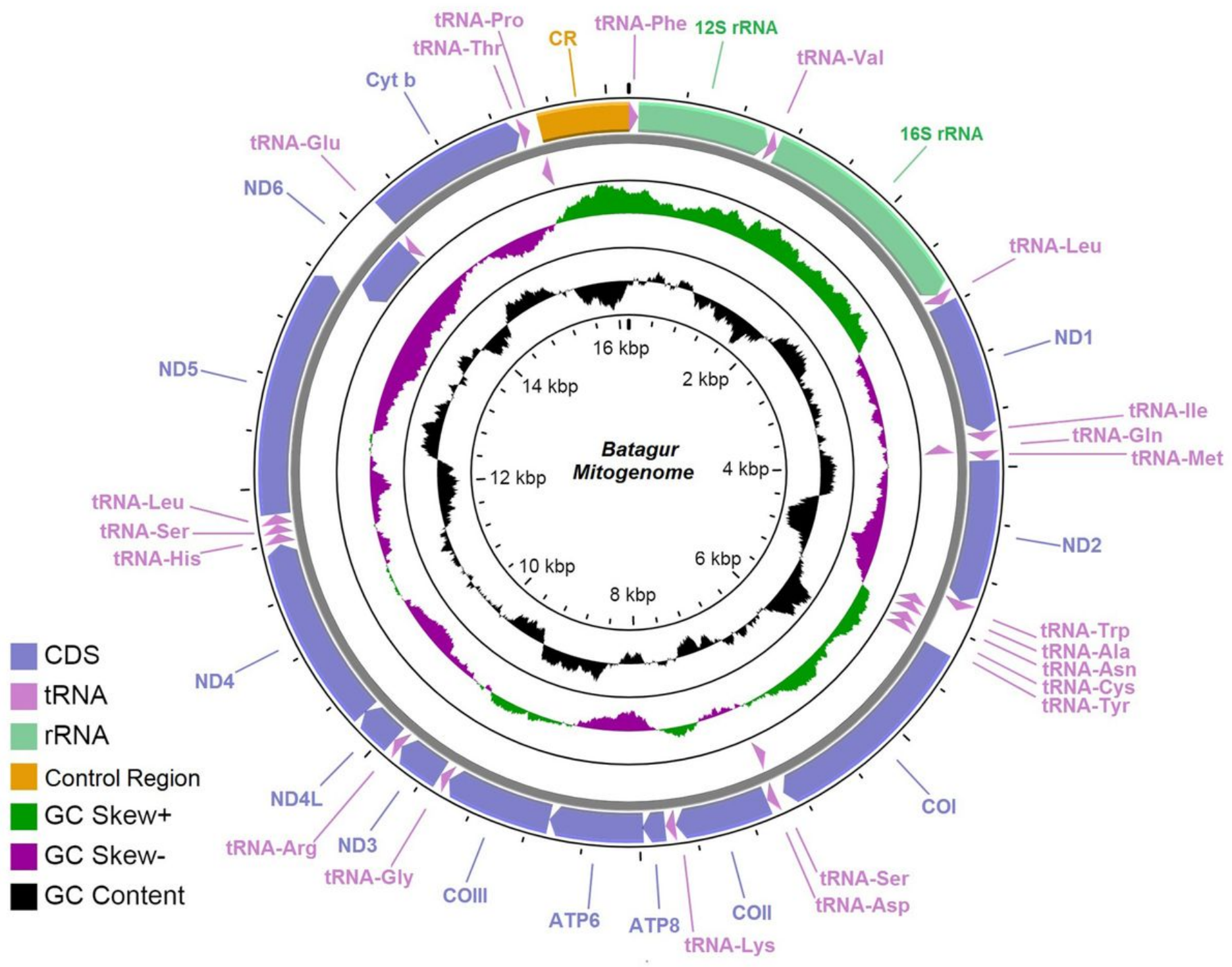

Figure 1

Circular mitochondrial genome map of Batagur kachuga and Batagur dhongoka. Genes encoded on the heavy strand or light strand are represented inside or outside the circular mitochondrial genome map. 


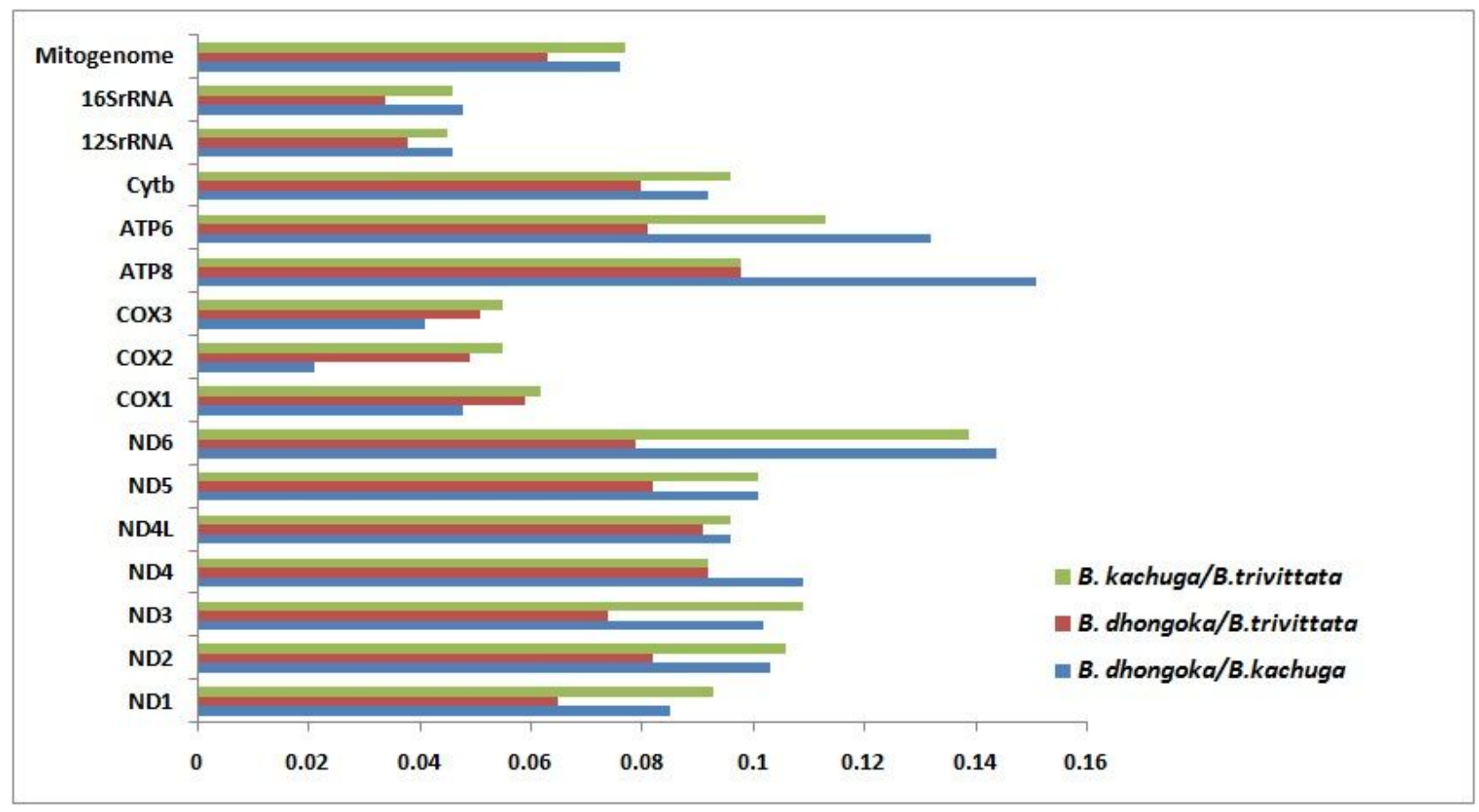

\section{Figure 2}

Graph showing gene-wise and mitogenomic genetic differentiation among Batagur kachuga, Batagur dhongoka and Batagur trivittata. 

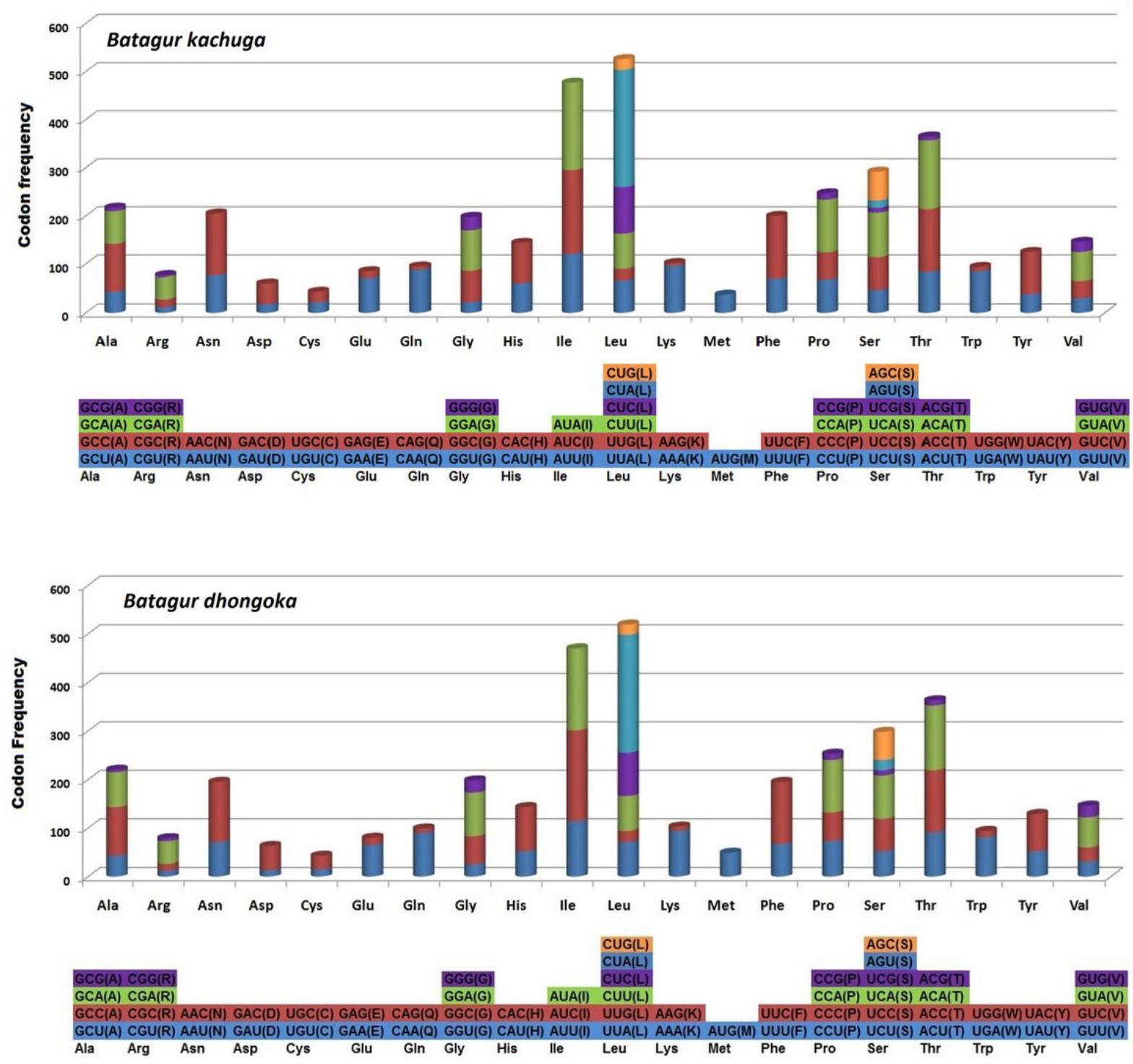

Figure 3

Comparison of codon usage among the mitochondrial protein-coding genes of Batagur kachuga and Batagur dhongoka. Codon families are plotted on the X-axis. 


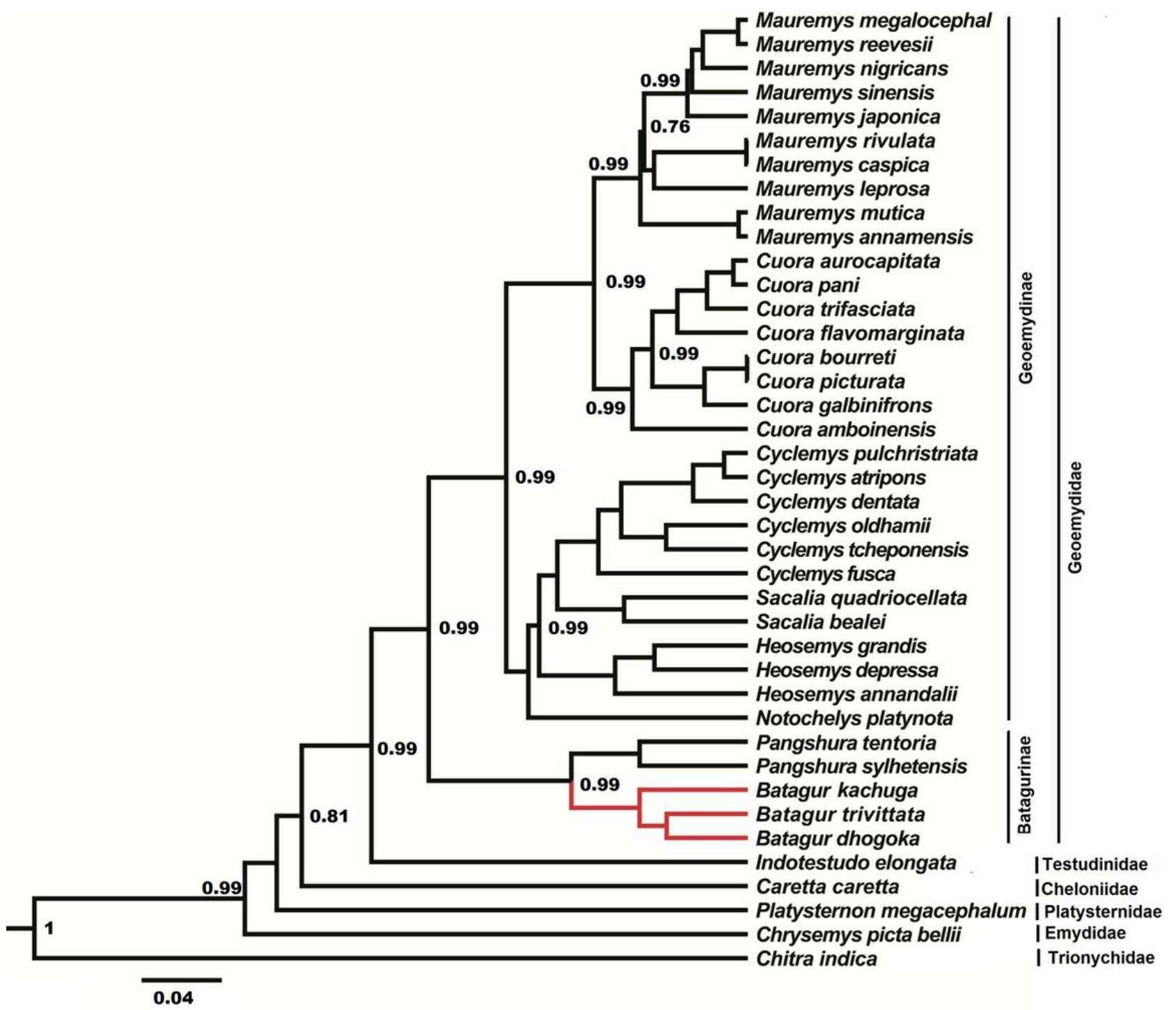

Figure 4

Phylogenetic relationship of Batagur species inferred from Bayesian inference (BI) analysis using 13 concatenated protein-encoding genes. Bayesian posterior probability (PP) values are shown at the nodes of the tree.

\section{Supplementary Files}

This is a list of supplementary files associated with this preprint. Click to download.

- SupplimentryMaterial.docx 